\title{
PENGARUH CORPORATE GOVERNANCE PADA HUBUNGAN ANTARA STRUKTUR MODAL DAN NILAI
}

\author{
HADI SAMANTO \\ STIE AAS Surakarta \\ hadisamanto@gmail.com
}

\begin{abstract}
ABSTRAK
Kajian ini bertujuan untuk fokus pada topik yang terkenal dalam literatur keuangan: hubungan antara struktur modal dan nilai perusahaan. hasil empiris yang kontroversial mengenai topik ini dapat dikaitkan dengan Variable kurangnya perhatian terhadap interaksi antara struktur permodalan dan tata kelola perusahaan lain. Bahkan, struktur modal corporate governance merupakan perangkat yang dapat melestarikan efesiensi perusahaan dan melindungi kemampuannya untuk menciptakan nilai.
\end{abstract}

Kata kunci : Corporate governance, stuktur modal

\section{PENDAHULUAN}

Setelah meninjau sintetis utama, mendefinisikan, dengan model deskriptif, sebuah pendekatan teoretis yang dapat berkontribusi dalam menjelaskan hubungan antara struktur modal, tata kelola perusahaan dan nilai. Penelitian ini memberikan proposisi, dan beberapa saran, yang harus diterapkan untuk masa depan riset empiris mengenai topik ini, sementara juga mempromosikan desain yang lebih tepat untuk analisis empiris.

Perdebatan mengenai hubungan antara struktur modal dan nilai perusahaan perlu mempertimbangkan langsung peran moderasi dan / atau mediasi dari tata kelola perusahaan. Perlu mempertimbangkan adanya saling melengkapi antara struktur permodalan dan tata kelola perusahaan, variabel lain seperti: konsentrasi kepemilikan, kepemilikan manajerial, peranan dewan direksi. 
Makalah ini mempromosikan, sebagai tujuan untuk riset masa depan, verifikasi validitas model ini melalui penerapan analisis untuk sampel berbagai perusahaan.

Makalah mencoba menyarankan bagaimana untuk meningkatkan analisis kontroversial pada topic sebelumnya.

Struktur modal: kaitannya dengan nilai perusahaan dan penelitian utama Ketika melihat kontribusi teoritis yang paling penting mengenai hubungan antara modal struktur dan nilai, segera menjadi jelas bahwa ada perbedaan besar antara teori-teori awal dan yang lebih baru. Teori-teori tersebut antara lain:

Secara khusus, kita dapat menunjukkan dgn jelas dari yang disajikan oleh Harris dan Ricky (1991) bahwa sumber utama bukti empiris menunjukkan bahwa laverage yang tinggi dan berkembang jika:

- sesuai dengan teori trade-off: penghasilan kena pajak tinggi dan biaya kesulitan keuangan rendah

- untuk teori: peluang pertumbuhan rendah dan / atau terdapat sejumlah besar aliran uang tunai yang tersedia,

- untuk teori asimetri informasi: informasi asimetri yang rendah dan keuntungan perusahaan tinggi (sebagai tanda keberhasilan)
Seperti banyak penulis telah mencatat (Rajan dan Zingales, 1995) struktur modal adalah"'topik panas di keuangan. Dengan menganalisis penelitian literatur internasional prioritas utama an analitis pendekatan baru yang berkaitan dengan:

- perbandingan rasional penting antara'"'dan"perilaku"keuangan (Barberis dan thaler, 2002)

- perbandingan hidup yang dibuat antara urutan kekuasaan teori dan teori trade-off (ShyamSunder dan Myers, 1999);

- upaya untuk menerapkan teoriteori ini kepada perusahaanperusahaan kecil (Berger dan Udell, 1998, Fluck, 2001);

- peran corporate governance pada hubungan antara struktur modal dan nilai (Heinrich, 2000, Bhagat dan Jefferis, 2002, Brailsford et al., 2004, MahrtSmith, 2005).

Akhirnya, pengamatan Michael Jensen (1986), membuat seluruh nya banyak kontribusi on corporate governance, serta orang-orang Williamson (1988), telah mendorong garis penelitian itu, direvitalisasi pada bagian kedua dari tahun sembilan puluhan, tampaknya cukup menjanjikan sebagai berarti untuk menganalisis bagaimana tata kelola perusahaan secara langsung atau tidak langsung mempengaruhi hubungan antara struktur modal dan nilai (Fluck, 1998, Zhang, 1998, Myers, 2000, De Jong, 2002, Berger 
dan Patti, 2003, Brailsford et al., 2004, Mahrt-Smith, 2005).

Dalam sintesis, adalah mungkin untuk menegaskan, bahwa analisis bergabung dengan struktur modal dan corporate governance adalah diperlukan saat menjelaskan dan menafsirkan kemampuan perusahaan untuk menciptakan nilai (Zingales, 2000, Heinrich, 2000, Bhagat dan Jefferis, 2002). Pertimbangan jenis ini bisa membantu mengatasi kontroversi ditemukan saat mempelajari hubungan antara struktur modal dan nilai, baik di tingkat teoretis dan empiris.

\section{Peranan corporate governance}

Teori-teori yang memiliki tujuan untuk menunjukkan bahwa mekanisme tata kelola perusahaan yang harus dipertimbangkan untuk membiarkan mengerti bagaimana struktur modal mempengaruhi nilai perusahaan, Teori tersebut antara lain:

Ekspresi corporate governance dapat mengambil dua makna, tergantung pada apakah penekanan yang lebih besar ditempatkan pada instrumen yang digunakan untuk mengalokasikan dan mengelola kekuasaan dalam suatu perusahaan, atau pada peran lembaga-lembaga eksternal dan mekanisme pengendalian efisiensi kegiatan perusahaan. Hal ini dapat didefinisikan sebagai:

- sistem pengambilan keputusan tentang bagaimana kekuasaan didistribusikan

dalam

perusahaan, sehingga untuk mengatasi masalah ketidaklengkapan kontrak antara berbagai pemangku kepentingan (manajerial atau internal corporate governance)

- seperangkat aturan, lembaga dan praktek-praktek yang dikembangkan untuk melindungi investor dari kewirausahaan dan manajerial perilaku oportunistik (kelembagaan atau eksternal corporate governance)

Tinjauan pustaka mekanisme mereka yang telah secara tradisional digunakan adalah yang ditawarkan oleh Shleifer dan Vishny (1997) dan oleh Denis (2001).

Pengaruh corporate governance pada hubungan antara struktur modal dan nilai

Teori yang mendasari:

- Struktur modal dapat dianalisis dengan melihat hak-hak dan atribut yang menjadi ciri aset perusahaan dan yang mempengaruhi, dengan tingkat intensitas yang berbeda, kegiatan pemerintahan. Equity dan utang, oleh karena itu, harus dipertimbangkan baik sebagai instrumen keuangan dan instrument

korporasi pemerintahan (Williamson, 1988). 
- Seperti yang secara eksplisit ditunjukkan oleh Bhagat dan Jefferis (2002), ketika mereka memberi perhatian khusus terhadap hubungan antara sebab dan akibat dan interaksi mereka.

- hubungan antara sebab dan akibat dan interaksi mereka baru-baru ini dijelaskan pada tingkat teoretis (Fluck, 1998, Zhang, 1998, Heinrich, 2000, Brailsford et al., 2004, Mahrt-
Smith, 2005) sebuah proposal penelitian"'"studi empiris masa depan harus mengevaluasi seharusnya, bagaimana tata kelola perusahaan yang dapat berpotensi memiliki pengaruh relevan pada hubungan antara struktur modal dan nilai, dengan efek mediasi dan / atau moderasi.

Key: Relation object of study
between capital structure and firm value
(relation A-B-C)
between capital structure and firm value
( relation $\mathrm{A}-\mathrm{D}$ )
role of the corporate governance and determinant of the capital
structure choice
(relation $\mathrm{E}$ )


Terdapat lima hubungan, yang menejelaskan tentang:

- hubungan antara struktur modal dan nilai perusahaan (hubungan A) melalui mediasi peran tata kelola perusahaan

- hubungan antara struktur modal dan nilai perusahaan (hubungan A) melalui moderasi peran tata kelola perusahaan

- peran corporate governance sebagai faktor penentu dalam pilihan mengenai struktur modal (relasi E) Semua lima hubungan ditunjukkan pada Gambar adalah sangat menarik dan menunjukkan dua benang penelitian yang berfokus pada hubungan antara:

1. struktur permodalan dan nilai, ditengahi (hubungan tidak langsung melalui intervensi lain variabel - relasi BCA) dan / atau dikurangi (hubungan langsung tetapi dikondisikan oleh variabel lain - hubungan AD) oleh variabel tata kelola perusahaan dan

2. corporate governance dan struktur modal, di mana dimensi perusahaan firm financing menentukan pilihan, menyebabkan kemungkinan hubungan kemungkinan co-causation. (relation $\mathrm{E}-\mathrm{B})$

Relasi tidak langsung

Capital structure $\longrightarrow$ corporate governance $\longrightarrow$ value

Hubungan langsung

Capital structure $\longrightarrow$ value (sebelumnya tersembunyi)

\section{SIMPULAN}

Penelitian ini menegaskan bahwa jika kebijakan investasi memungkinkan penciptaan nilai, kebijakan pembiayaan, bersama-sama dengan instrumen pemerintahan yang lain, dapat memastikan bahwa investasi kebijakan dilakukan secara efisien sementara nilai perusahaan dilindungi dari perilaku oportunistik. Sebagai kesimpulan, jurnal mendefinisikan sebuah model teoretis yang memberikan kontribusi untuk memperjelas hubungan antara struktur modal, corporate governance dan nilai perusahaan, sementara mempromosikan, sebagai suatu tujuan untuk riset masa depan, sebuah verifikasi keabsahan model ini melalui penerapan analisis untuk sampel berbagai perusahaan dan perusahaan tunggal. Untuk mempelajari interaksi antara struktur modal, corporate governance dan nilai ketika menganalisis berbagai sample 
perusahaan memperhitungkan peneliti harus hubungan menunjukkan masalah endogeneity dan kausalitas timbal balik, dan pastikan ada komplementaritas antara semua tiga faktor. Selain itu, hubungan ini harus diselidiki dalam analisis lintas negara, untuk menangkap peran faktor spesifik Negara . Sebuah pengamatan terakhir menunjukkan bahwa studi klinis harus mendahului analisis kuantitatif, sehingga dapat memverifikasi model teoretis dalam satu kasus dan pastikan bahwa implikasi dugaan yang benar. 


\section{DAFTAR PUSTAKA}

Nunung

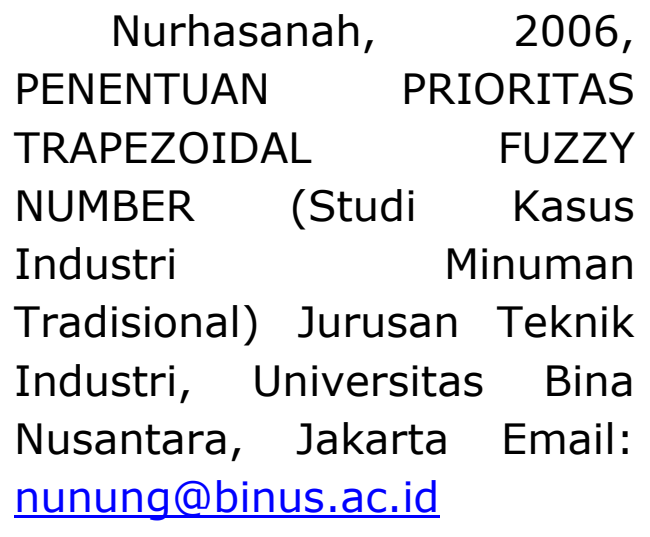

Trisno Musanto, 2004, Faktor-Faktor Kepuasan Pelanggan dan Loyalitas Pelanggan: Studi Kasus pada CV. Sarana Media Advertising Surabaya, Staf Pengajar Tetap Fakultas
Ekonomi Universitas Katolik Widya Mandala Surabaya

$\begin{array}{rrr}\text { Mulyadi, } 1999, \text { Sistem } & \text { Perencanaan } \\ \text { dan } & \text { Pengendalian } \\ \text { Manajemen } & : \quad \text { Sistem } \\ \text { Pelipatganda } & \text { Kinerja } \\ \text { Perusahaan, Edisi satu, } & \text { satu, } \\ \text { Yogyakarta : Adiya Media }\end{array}$

Robert N. Anthony, Vijay Govindarajan 2007, Management Control Systems 12th Edition, McGraw-Hill

Mudrajad Kuncoro, SE, M.Soc.Sc 2007, Struktur Organisasi dan Pengendalian/www.mudrajad .com 